\title{
The Association of Religiosity and Political Conservatism: The Role of Political Engagement
}

\author{
Ariel Malka \\ Yeshiva University \\ Yphtach Lelkes \\ Stanford University \\ Sanjay Srivastava \\ University of Oregon \\ Adam B. Cohen \\ Arizona State University \\ Dale T. Miller \\ Stanford University
}

\begin{abstract}
Some argue that there is an organic connection between being religious and being politically conservative. We evaluate an alternative thesis that the relation between religiosity and political conservatism largely results from engagement with political discourse that indicates that these characteristics go together. In a combined sample of national survey respondents from 1996 to 2008, religiosity was associated with conservative positions on a wide range of attitudes and values among the highly politically engaged, but this association was generally weaker or nonexistent among those less engaged with politics. The specific political characteristics for which this pattern existed varied across ethno-religious groups. These results suggest that whether religiosity translates into political conservatism depends to an important degree on level of engagement with political discourse.
\end{abstract}

KEY WORDS: religion, political attitudes, political engagement, conservative ideology, social influence

In the contemporary United States, highly religious individuals tend, on average, to hold more conservative political positions than do less religious individuals (Guth, Kellstedt, Smidt, \& Green, 2006; Kelly \& Morgan, 2008; Layman \& Carmines, 1997; Layman \& Green, 2005; Olson \& Green, 2006). Two broad frameworks for addressing the religion-politics relation may be identified within contemporary scholarship. One posits an organic connection between high versus low religiosity and conservative versus liberal political attitudes (Alford, Funk, \& Hibbing, 2005; Graham, Haidt, \& Nosek, 2009; Hunter, 1991; Jost, 2007; Jost, Nosek, \& Gosling, 2008). That is, some of the values and predispositions that characterize religiosity naturally lead people to favor 
conservative social outcomes and policies. The other framework posits a contextually driven relation between these constructs. Specifically, the religious elites of various denominations and traditions convey to the laity that they ought to espouse conservative political views, and messages from political discourse convey that the combination of religiosity and conservatism is natural and appropriate (Guth, Green, Smidt, Kellstedt, \& Poloma, 1997; Layman, 2001; Layman \& Green, 2005). This context of information leads religious individuals to adopt more conservative political attitudes than they otherwise would.

These two perspectives are not mutually exclusive. Religiosity may relate to political conservatism to some extent because of an organic linkage and to some extent because of messages from religious and political discourse. However, we contend that this link results primarily from certain segments of the population engaging with political discourse that suggests a natural connection between religiosity versus secularism and conservatism versus liberalism. The primary hypothesis of this research is that robust links between religiosity and conservative political positions only exist among those who are relatively engaged with political discourse - that is, among those who are relatively interested in and knowledgeable about politics. We predict a substantially smaller relation, or no relation at all, among people who are not strongly engaged with politics. In addition, we examine whether this moderation is present among all, or only among some, of the major American ethno-religious groups.

\section{Organic Connections between Religiosity and Conservative Politics}

Some social scientists have argued that there exists a natural connection between religiosity (vs. secularism) and conservative (vs. liberal) politics. According to this view, the values and preferences associated with religiosity are naturally linked with conservative preferences. This position is consistent with the "culture wars" framework for describing the contemporary American political climate (Hunter, 1991). The culture wars framework depicts a bitter political schism between religious conservatives and secular liberals, rooted in contrasting worldviews so deep-seated that their resultant division is nearly unbridgeable.

According to Hunter (1991), the two opposing sides of the culture war possess radically "different systems of moral understanding" (p. 42). The religiously traditional possess fundamentally different worldviews from the religiously progressive and the secular, and these differences have implications not only for their stances on cultural issues, but also for their stances on other political issues described with reference to the conservative-liberal dimension (such as economic issues). In line with this view, Graham et al. (2009) argue that liberals and conservatives possess different foundations for moral judgments such that the latter are more concerned with the religiously relevant matters of purity and sanctity. Graham et al. (2009) suggest that these differences have implications for the American culture war.

Jost and colleagues offer a framework for understanding the psychological connection between political conservatism and a range of nonpolitical characteristics, including those related to religiosity (e.g., Jost, 2006; Jost, Glaser, Kruglanski, \& Sulloway, 2003). They define conservatism as resistance to both change and equality and argue that it is driven by certain dispositional and situationally evocable social cognitive motives (Jost et al., 2003; Jost et al., 2008; Thorisdottir, Jost, Leviatan, \& Shrout, 2007). They argue that the motives that underlie conservatism also underlie a variety of other characteristics, including religious inclinations, and that this helps to explain an apparent historical continuity in the relation between religiosity and political conservatism (Jost, 2007; Jost et al., 2008). Similarly, Alford and colleagues (2005) contend that religiosity and conservative political preferences "are related cultural expressions of a deep-seated genetic divide in human behavioral predispositions and capabilities" (p. 165). 


\section{Engagement with Political Discourse and the Religiosity-Politics Relation}

Various aspects of the culture wars thesis have been challenged (Davis \& Robinson, 1996; Fiorina, Abrams, \& Pope, 2006; Hillygus \& Shields, 2005; Layman \& Green, 2005; Williams, 1997). Of particular importance, most Americans do not fit neatly into one of the polarized camps posited by this framework, and the very prominence of this framework in discourse appears to influence the Americans who are exposed to it. In line with these challenges, we contend that the contemporary religious divisions in political positions primarily result from aspects of the social context and the manner in which people respond to them. The context to which we refer is that of political communication, involving the views and messages of political elites (Bartels, 1993; Converse, 1964; Zaller, 1992). People are influenced by this context of information via both direct exposure to the news media (e.g., Iyengar \& Kinder, 1987; Mutz, 1998) and exposure to informal political communication (e.g., from clergy, family, friends, and coworkers) whose content is ultimately influenced by news media content (e.g., Katz \& Lazarsfeld, 1955; Mutz, 2002). We argue that engagement with messages that religiosity "goes with" conservatism plays an important role in the relation between these characteristics. We base this view on (a) the historical variability in the influence of religion on political attitudes and behaviors and (b) the role of political engagement in the structuring of political attitudes.

\section{Ethno-Religious Groups, Religiosity, and Politics in the United States}

When discussing the role of religion in politics, it is important to distinguish religiosity from the related and more familiar construct of ethno-religious group. Ethno-religious group refers to the particular religious tradition with which the individual identifies, historically encompassing both distinct religious affiliations and other cultural characteristics such as racial-ethnic group (Guth et al., 2006; Layman \& Green, 2005; Steensland et al., 2000; Wald, 2003). Religiosity refers to religious commitment, as indicated by both religious behaviors and subjective religious beliefs (Layman \& Carmines, 1997; Pew Forum on Religion \& Public Life, 2005; Stark \& Finke, 2000).

The major American ethno-religious groups are, in no particular order, Evangelical Protestantism, Mainline Protestantism, Black Protestantism, and Roman Catholicism. The distinctions among Protestants are based on the historical development of Protestant religious groupings (Guth et al., 2006; Leege \& Kellstedt, 1993; Smidt, Kellstedt, \& Guth, 2009; Steensland et al., 2000). The original defining features of Mainline Protestantism were a tolerance of modernization and belief differences and an emphasis on promoting social justice. Evangelical Protestantism has historically emphasized literal interpretations of scripture and the born-again experience (Hunter, 1991; Kellstedt \& Green, 1993; Steensland et al., 2000). Black Protestantism emerged under distinct historical circumstances unique to the Black American experience and has emphasized freedom and rectification of prior injustice (Lincoln \& Mamiya, 1990; Roof \& McKinney, 1987; Wilcox \& Larsen, 2006).

Historically, ethno-religious group memberships have been associated with political behavior (Guth et al., 2006; Layman, 2001; Smidt et al., 2009; Wald, 2003; Wuthnow, 1988). From the onset of the New Deal until the mid-1960s, White Catholics, White Evangelical Protestants, and Black Protestants tended to support the Democratic Party, whereas White Mainline Protestants tended to vote Republican. Ethno-religious group was one of several social cleavages, including social class and region, that mapped onto political preferences. Since the mid-1960s, however, the links between ethno-religious group and political preferences have changed, in many cases weakening (Hunter, 1991; Kohut, Green, Keeter, \& Toth, 2000; Layman, 2001; Smidt et al., 2009). White Catholics and White Mainline Protestants have become more evenly divided in their political allegiances, White Evangelical Protestants have moved to the Republican Party, and Black Protestants have become almost uniformly Democratic. 


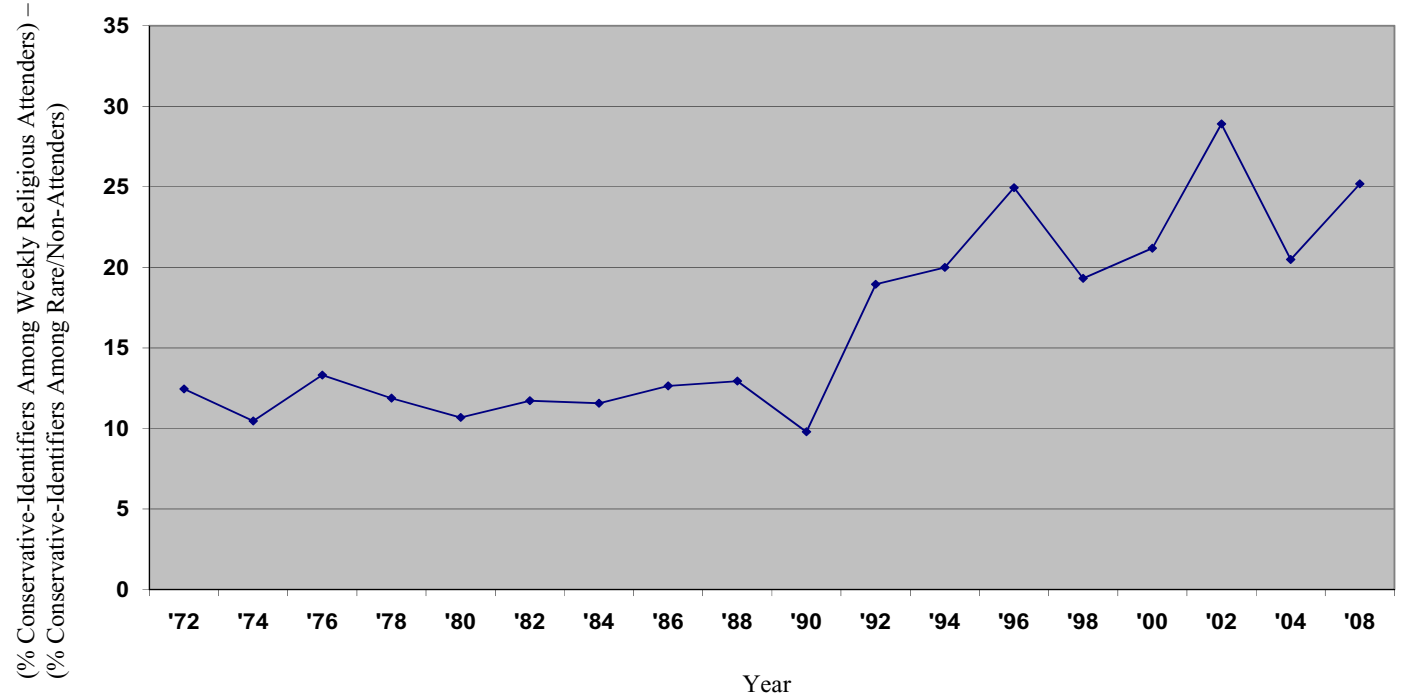

Figure 1. Percent identifying as "conservative": Difference between weekly religious attenders and rare/nonattenders (American National Election Studies).

The association between religiosity and political leanings has followed a different trajectory. The association between religiosity and Republican vote appears to have steeply increased in 1992 and to have remained far above pre-1992 levels ever since (Fiorina et al., 2006, p. 132). This increase may simply reflect temporal changes in the candidate options presented to citizens rather than temporal changes in the political preferences of religious versus secular people (Fiorina et al., 2006). We conducted preliminary analyses that suggest, however, that religiosity has not only become more strongly associated with vote choice, but that it has also become more strongly associated with conservative self-identification. Figure 1 displays the difference between the percent of frequent (i.e., weekly) religious attenders who identified as conservative and the percent of infrequent attenders (i.e., those who attend a few times per year or never) who identified as conservative during every election year since 1972. ${ }^{1}$ This difference hovered in the range of 10-14\% from 1972 through 1990, before undergoing a sharp increase in 1992. From 1992 through 2008 the difference varied from around $19 \%-29 \%$.

Indeed, religiosity is nowadays associated with a conservative orientation across a range of issues. This relation is strongest among White Evangelical Protestants, but is also generally found among White Mainline Protestants and among White Catholics (Guth et al., 2006; Layman \& Green, 2005; but see Gallup, 2009). Among Black Protestants, in contrast, religiosity tends to relate to liberal preferences on several issues (Layman \& Green, 2005). Not surprisingly, religiosity has a far stronger relation with cultural policy positions, such as abortion, than it has with other policy positions (Guth et al., 2006; Jelen, 2009; Layman \& Green, 2005).

The thesis of this article is that religiosity goes with conservatism nowadays primarily because contemporary political discourse suggests that these two characteristics go together. This pattern of discourse began in the 1970s when the contemporary religious conservative movement came into being and has gained prominence during the subsequent decades (Gerring, 1998; Hunter, 1991;

${ }^{1}$ This graph excludes 2006, during which no American National Election Studies (ANES) time series survey was administered 
Layman, 2001; Wald, 2003), especially during the early to mid-1990s (Fiorina et al., 2006; Layman, 2001). But it has not reached all Americans to an equal extent.

\section{Political Engagement and Political Attitudes}

Since Converse's (1964) seminal essay, among the most reliable findings in the political attitudes literature has been that "constraint" - the tendency to adopt a consistently liberal or a consistently conservative package of attitudes, and to hold political attitudes that are consistent with one's ideological self-identification - tends to be present only among individuals who are relatively engaged with politics (Baldassari \& Gelman, 2008; Jacoby, 1995; Judd \& Krosnick, 1989; Sniderman, Brody, \& Tetlock, 1991; Stimson, 1975; Zaller, 1992). More recently, research has suggested that even the relations between "prepolitical" characteristics and political attitudes are stronger, or are only present, among the politically engaged (Federico \& Goren, 2009; Federico, Hunt, \& Ergun, 2009).

The explanation for this type of finding generally favored by political scientists is that those who are engaged with politics are more likely to adopt one of the configurations of attitudes and identities that they view (correctly) as prevalent among political elites (Converse, 1964; Sniderman \& Bullock, 2004; Zaller, 1992). We presently test the hypothesis that political discourse not only influences the alignment of political positions on the right-left dimension, but also the alignment of political positions with the nonpolitical cultural attribute of religiosity. We contend that religiosity does not have strong natural linkages with most conservative preferences; rather, people derive conservative preferences from their religious commitment mainly because of engagement with political discourse.

\section{The Present Research}

We test whether the relation between religiosity and conservatism is stronger among people who are politically engaged than it is among people who are not politically engaged. We do so using a large combined sample of national survey respondents from1996 through 2008.

Political engagement is examined as a moderator of the associations between religiosity and a wide variety of political characteristics, including a range of policy preferences (e.g., social welfare and cultural), core political values (equality and opposition to change), and political identities (partisan and ideological). We predict that political engagement will enhance the connections between religiosity and each one of these political characteristics, given that many political domains are nowadays discussed with reference to the conservative-liberal dimension.

Given the historical political importance of ethno-religious groups, it is important to document what role, if any, ethno-religious group memberships play in the phenomenon under study. It may be the case that the combination of being politically engaged and religious is more common among particular ethno-religious groups and that ethno-religious group membership therefore accounts for the interactive influence of religiosity and political engagement on conservatism. To test this possibility we include as control variables sets of codes representing the effects of ethno-religious group. It is also possible that political engagement only moderates the association of religiosity and conservatism among some ethno-religious groups but not among others. This may occur because only the politically engaged members of certain ethno-religious groups translate religiosity into conservative attitudes or because people with particular combinations of political engagement, religiosity, and political attitudes opt into religious denominations with which they are most comfortable (see Pew Forum on Religion and Public Life, 2009). We therefore test political engagement as a moderator of the religiosity-politics relation within each of the major ethno-religious groups. 


\section{Method}

\section{Participants}

Respondents to the ANES time series surveys from the years 1996, 2000, 2004, and 2008 served as this study's participants. The numbers of respondents in each year were 1,714 in 1996, 1,807 in $2000,1,212$ in 2004 , and 2,323 in 2008 . $^{2}$ Thus the total sample size is 7,056, although sample sizes vary across analyses. Analyses are weighted to adjust for demographic nonrepresentativeness.

\section{Measures}

The items that were selected to measure each of the key variables are listed in the appendix, along with internal reliability coefficients where relevant. To represent ethno-religious group, sets of dummy codes were generated for White Evangelical Protestant, White Mainline Protestant, Black Protestant, White Catholic, White nontraditional Protestant, Jewish, and other religions. The comparison category was individuals with no religious affiliation. ${ }^{3}$

The remaining key measures consisted of items involving forced-choice responses, or correct versus incorrect answers. Each composite was computed for a participant if he/she was administered and provided a usable response to at least $50 \%$ of the items comprising the composite. All items assessing policy preferences, values, or identities were coded so that higher scores correspond with a "conservative" position. Indicators that were combined into composites were first transformed into a common scale, and all variables used in analyses were coded to range from 0 to 1 in order to facilitate the interpretation of unstandardized regression coefficients. As indicated in the appendix, certain items were not administered in all of the years or for all of the respondents within a particular year. In these cases, respondents who were not administered particular items were counted as not having provided usable responses to those items. Finally, items were sometimes administered with slightly different wording or response options either across or within years. Such cases are noted in the footnotes of the appendix.

The religiosity measure was formed as a composite of religious attendance and rating of how much guidance religion provides in one's life $(r=.58, p<.001)$.

\footnotetext{
${ }^{2}$ The 2008 ANES cross-section included racial-ethnic minority oversamples.

${ }^{3}$ Ethno-religious group designations were determined on the basis of religious denomination, racial-ethnic group, and, in some cases, self-identification as Evangelical or Fundamentalist, self-reported born-again experience, and liturgical literalism (Layman \& Green, 2005; The Pew Forum on Religion and Public Life, 2008; Smidt et al., 2009). Ethno-religious group memberships were assigned to both participants who did and did not attend a place of worship. Blacks who indicated a Protestant affiliation ( $84 \%$ of Blacks) were categorized as Black Protestant (11.1\% of the sample) and the remaining Christian ethno-religious groups consisted of non-Blacks (Layman \& Green, 2005; Smidt et al., 2009). A small number of non-black Protestants indicated a "non-traditional" Protestant affiliation (2.4\% of the sample), such as Latter Day Saints or Jehovah's Witnesses, and were categorized as non-traditional Protestant. The remaining non-Black Protestants were categorized as White Evangelical or White Mainline ("White" because these major non-Black Protestant ethno-religious groups are predominantly white), based primarily on their specific Protestant denominational affiliations (Smidt et al., 2009; Steensland et al., 2000). However, some non-black Protestants did not report sufficiently detailed denominational information to allow for categorization as Evangelical or Mainline. Such Protestants were categorized based on self-identification as Evangelical or Fundamentalist when this item was available (1996), self-reported born-again experience when this item was available but Evangelical/Fundamentalist self-identification was not (2008), and liturgical literalism when neither of the aforementioned items was available (2000 and 2004) (e.g., Layman \& Green, 2005; Steensland et al., 2000). Using this procedure, $23.6 \%$ of the sample was categorized as White Evangelical Protestant and $19.0 \%$ of the sample was categorized as White Mainline Protestant. Non-black (hereafter, "White") Catholics comprised $22.9 \%$ of the sample, Jews comprised $1.8 \%$ of the sample, individuals with other religious affiliations comprised $2.5 \%$ of the sample, and individuals with no religious affiliation comprised $16.8 \%$ of the sample. Despite minor differences in the method of categorizing respondents into ethno-religious groups, these percentages closely match those obtained from the U.S. Religious Landscape Survey (The Pew Forum on Religion and Public Life, 2008, p. 5).
} 
We conceptualize political engagement as overall involvement with political information, as manifested by (a) high (vs. low) subjective importance of politics and (b) high (vs. low) objective political knowledge (Campbell, Converse, Miller, \& Stokes, 1960; Delli Carpini \& Keeter, 1996; Zaller, 1992). These indicators tend to be correlated, but they are conceptually distinguishable. Consistent with our broad conceptualization of political engagement, we used a political engagement composite consisting of both interest and knowledge indicators. However, recognizing that interest and knowledge are conceptually distinguishable manifestations of overall engagement, we also individually tested interest and knowledge as moderators.

Political interest was operationalized as a composite of six items including interest in presidential campaigns, interest in government and public affairs, and frequency of newspaper reading. Political knowledge was operationalized as a composite of correct (coded 1) versus incorrect (coded 0 ) responses to five factual political questions. A political engagement composite was computed by averaging across the political interest and political knowledge composites ( $\alpha$ across the 11 items $=.75)$.

Composites were computed for social welfare, cultural, and racial policy preferences by averaging the relevant items. Single-item indicators were selected for environmental, immigration, defense, death penalty, and gun control policy preferences. Composites were computed for inequality and oppose change values. Party identification and ideological identification were measured with the standard seven-level indicators. Finally, we computed a political orientation composite by averaging across all of the political characteristics among individuals with scores on at least half of them $(\alpha=.82)$.

Besides ethno-religious group, the following demographic characteristics were included in analyses as control variables: sex, age, education (college vs. no college), residence in the South, household income, household union membership, and Hispanic ethnicity. Dummy coded variables representing the effects of year of survey were also included as controls.

\section{Results}

\section{Associations of Ethno-Religious Group Memberships and Political Characteristics}

We first examined the associations of ethno-religious group memberships and each of the political attitudes, values, and identities. Each of the political characteristics was individually regressed on the dummy coded ethno-religious group variables and the control variables. The results of these analyses are displayed in Table 1 .

White Evangelical Protestants, White Mainline Protestants, and White Catholics all tended to adopt conservative stances across a range of political characteristics relative to the comparison category of individuals with no religious affiliation (Rows 1, 2, and 4 of Table 1). Evangelical Protestants did so across all of the political characteristics, White Mainline Protestants did so across all of the political characteristics except for gun control preference, and White Catholics did so across most of the political characteristics.

Black Protestants tended to adopt liberal stances relative to those with no religious affiliation (Row 3, Table 1), although they held conservative positions relative to this group on cultural issues, opposition to change, and ideological self-label. Also, Black Protestants did not differ from the religiously unaffiliated on environmental, immigration, and defense preferences. ${ }^{4}$

\footnotetext{
${ }^{4}$ Additional analyses revealed that compared to Black non-Protestants, Black Protestants were more inclined to adopt the conservative position on cultural issues $(b=.05, p<.05)$, environmental spending $(b=.05, p=.063)$, immigration $(b=.08$, $p<.01)$, and opposition to change $(b=.04, p<.05)$, and more likely to identify as Democratic $(b=-.04, p=.059)$.
} 


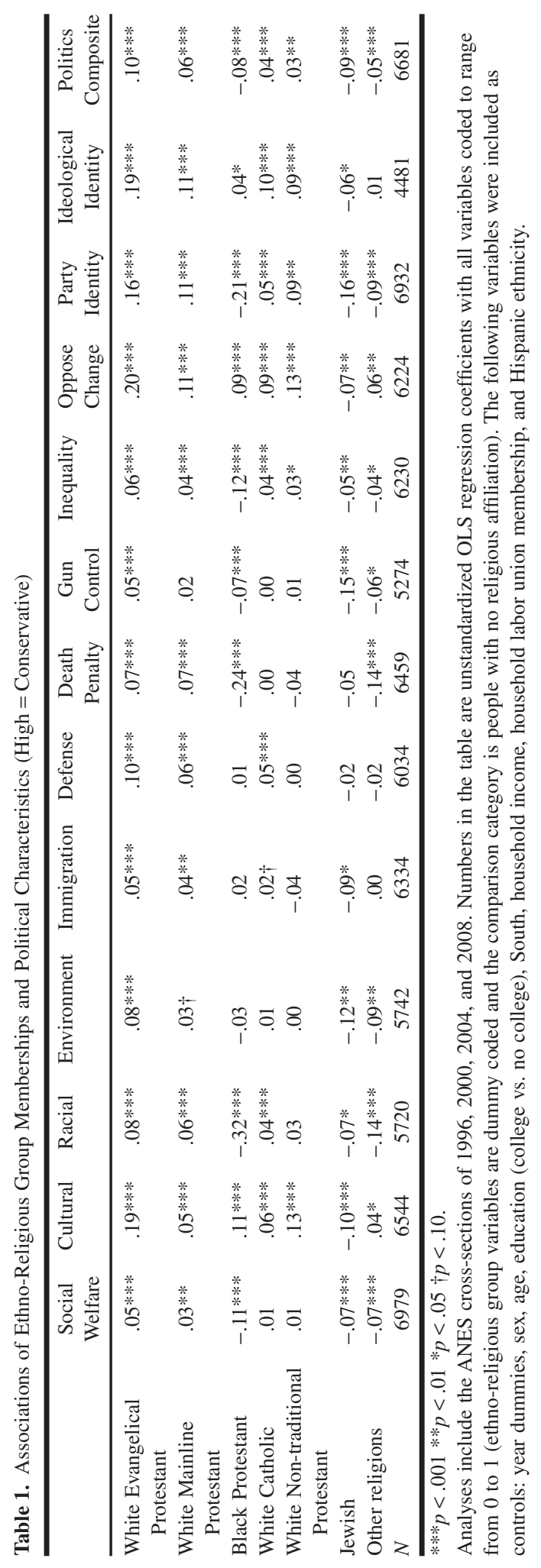


Another set of analyses (not reported in Table 1) examined differences between the four major ethno-religious groups on the political orientation composite. White Evangelical Protestants were the most conservative, followed by White Mainline Protestants, White Catholics, and then Black Protestants ( $p s<.001$ for all comparisons). The religiously unaffiliated were to the left of White Catholics but to the right of Black Protestants.

\section{Associations of Religiosity and Political Characteristics}

We next tested whether religiosity significantly predicted political attitudes, values, and identities independently of ethno-religious group memberships. ${ }^{5}$ Table 2 displays the zero-order correlations between religiosity and each political characteristic, as well as the unstandardized regression coefficients for the effects of the former on the latter with control variables entered. These coefficients are displayed for all respondents (top two rows of Table 2), for members of each of the major ethno-religious groups (third through tenth rows of Table 2), and for respondents with no religious affiliation (bottom two rows of Table 2).

Consistent with prior findings, religiosity generally predicted a right-leaning orientation toward politics among the entire sample (e.g., Guth et al., 2006; Layman \& Green, 2005; Layman \& Carmines, 1997). ${ }^{6}$ It did so for all political characteristics besides racial, immigration, death penalty, and gun control policy preferences. Religiosity was associated with a general right-leaning political orientation, represented by the composite. Consistent with prior research (Davis \& Robinson, 1996; Guth et al., 2006; Layman \& Green, 2005), religiosity's strongest relations were with cultural policy preferences and the value presumed to underlie cultural policy preferences, opposition to change. Religiosity also possessed a relatively strong relation with ideological identification. When religiosity did predict noncultural issue stances and values, the effects were small. In contrast to this pattern, but consistent with prior research (Gallup, 2004), religiosity was associated with opposition to the death penalty.

The effects of religiosity reported above were not attributable to ethno-religious group differences in religiosity, as dummy coded variables representing the effects of ethno-religious group memberships were controlled for. Thus, religious people did not tend to hold conservative views simply because they tended to have particular religious affiliations. However, the associations of religiosity and political characteristics did vary across ethno-religious groups. As in prior research (e.g., Guth et al., 2006; Layman \& Green, 2005), the associations were strongest and most consistent among

\footnotetext{
${ }^{5}$ The correlation between religiosity and a dummy coded variable for no religious affiliation vs. all other respondents was $-.47(p<.001)$. Thus religiosity is not redundant with identification with any religious affiliation vs. identification with no religious affiliation. Indeed, prior findings indicate that there is meaningful variation in religiosity among both Americans who identify with a religious affiliation and among Americans who do not (Pew Forum on Religion and Public Life, 2008; Smidt et al., 2009).

${ }^{6}$ As in prior research, the present analyses involve the use of a composite of indicators of religious attendance and religious importance (e.g., Green, Guth, \& Fraser, 1991; Hill \& Pargament, 2003; Layman \& Carmines, 1997; Layman \& Green, 2005). We conducted additional analyses to examine whether religious attendance and religious importance would display the same pattern of relations with the political characteristics. They did. Separately examining religious attendance and religious importance as predictors of the political variables, we obtained very similar coefficients for the two religiosity indicators. When rounded to the second decimal place, the effect of religious attendance on the political orientation composite was identical to the effect of religious importance on the political orientation composite (in both cases, $b=.05, p<.001$ ).

Additional analyses revealed, however, that the religious attendance $\times$ religious importance interaction predicted social welfare $(b=.06, p<.01)$, cultural $(b=.17, p<.001)$, racial $(b=.12, p<.01)$, environmental $(b=.09, p<.05)$, and gun control policy preferences $(b=.06, p=.086)$, as well as opposition to change value $(b=.08, p<.001)$, party identification $(b=.17, p<.001)$, ideological identification $(b=.12, p<.001)$, and the political orientation composite $(b=.06, p<.001)$. Adding religious attendance squared and religious importance squared to these equations (Ganzach, 1997) did not importantly change these results. Thus, for most of the political attitudes sampled, the degree to which religious importance is associated with conservative political views depends on frequency of religious attendance (and vice versa). This is consistent with the view that the translation of subjective religiosity into political conservatism depends on the person's level of exposure to clergy and religious congregants (Layman \& Green, 2005; Smidt et al., 2009). Future research should further explore this idea.
} 


$$
\underline{n}
$$


White Evangelical Protestants, followed distantly by White Mainline Protestants. Among the religiously unaffiliated, religiosity was slightly correlated with conservative political orientation, but this effect became marginally significant with the control variables entered. Among White Catholics, religiosity was uncorrelated with the political orientation composite, and among Black Protestants, religiosity was slightly negatively associated with conservative political orientation. ${ }^{7}$ Consistent with the messages that predominate Black religious discourse, religiosity, for example, was associated with liberal social welfare policy views among this group. Also, while one might expect to find an association between religiosity and opposition to the death penalty only among Black Protestants and White Catholics, such an association was in fact observed among all of the groups.

\section{Political Engagement as a Moderator of the Associations of Religiosity and Political Characteristics}

We next proceeded to test our primary hypothesis: that the relations between religiosity and conservative political characteristics would hold to a significantly stronger extent, or exclusively, among those who were relatively engaged with politics.

As displayed in the third row of Table 3, we obtained a good deal of support for this hypothesis. This row displays the effect of the political engagement $\times$ religiosity interaction on each of the political characteristics among the entire usable sample, with political engagement (mean-centered), religiosity (mean-centered), and the control variables in the equation. Political engagement moderated the relations between religiosity and social welfare $(b=.10, p<.001)$, cultural $(b=.08$, $p<.05)$, racial $(b=.18, p<.001)$, environmental $(b=.20, p<.001)$, defense $(b=.18, p<.001)$, death penalty $(b=.23, p<.001)$, and gun control policy preferences $(b=.08, p=.082)$. Political engagement moderated the relation between religiosity and both of the core values-inequality $(b=.09, p<.01)$ and oppose change $(b=.18, p<.001)$ - and the relation between religiosity and party identification $(b=.31, p<.001)$. The only political characteristics whose relations with religiosity were not significantly or near-significantly (i.e., at $p<.10$ ) moderated by political engagement were immigration policy preference $(b=.03, p=.630)$ and ideological identification $(b=.06$, $p=.161)$. Political engagement significantly moderated the relation between religiosity and the political orientation composite $(b=.15, p<.001)$.

As displayed in the bottom two rows of Table 3, the relation between religiosity and conservative views tended to exist to a stronger extent, or to only exist, among those relatively high in political engagement. These rows display the simple slopes for the effects of religiosity on the political characteristics for hypothetical individuals +1 and -1 SD from the mean on political engagement. Among people high in political engagement, religiosity was associated with conservative positions on every political characteristic except for immigration and death penalty, and religiosity was associated with a conservative orientation as indicated by the political orientation composite $(b=.10$, $p<.001)$. Thus, in general, religiosity corresponds with conservatism among the highly politically engaged. In contrast, among people low in political engagement, religiosity was not positively associated with 8 out of the 12 unique political characteristics assessed and was relatively weakly associated with the political orientation composite $(b=.03, p<.001)$. Religiosity was associated with conservative cultural stances, opposition to change, Republican identification, and conservative identification among these individuals, but to a (in three cases significantly) lesser extent than it was among the politically engaged. Among those low in political engagement, religiosity was relatively strongly associated with opposition to the death penalty, whereas this relation was significantly smaller among those high in political engagement.

\footnotetext{
${ }^{7}$ Whereas among Black Protestants there was a negative relation between religiosity and the political orientation composite, among Black non-Protestants there was a near-significant positive relation $(b=.05, p=.054)$ between these variables.
} 


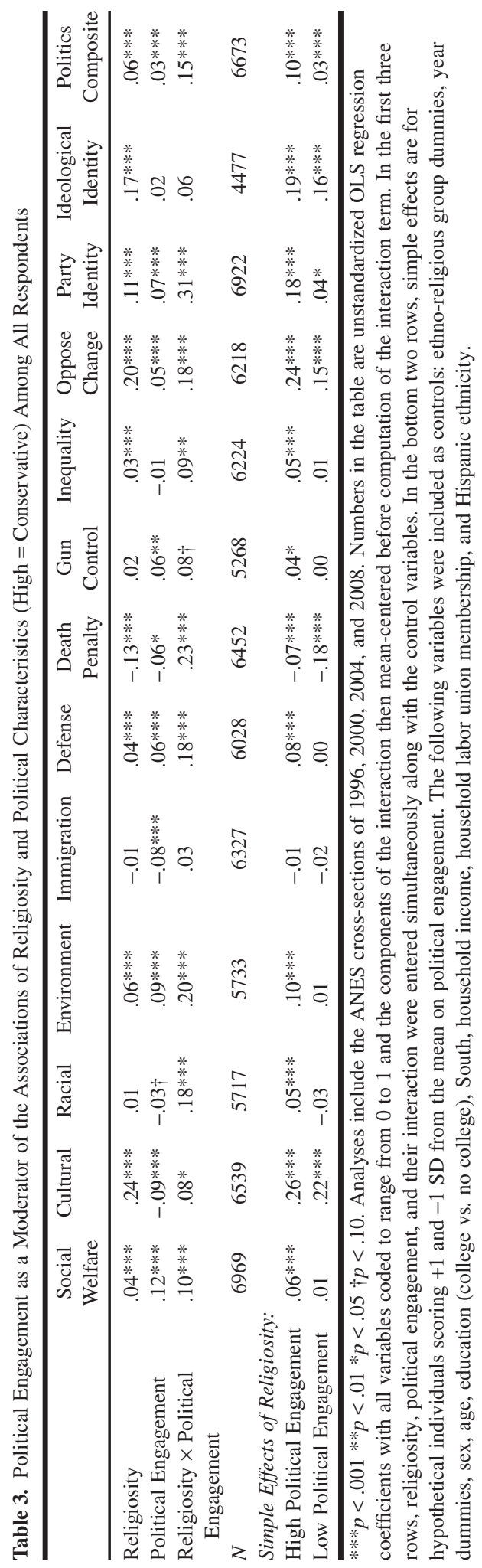


In sum, religiosity's relations with most of the political characteristics assessed were moderated by political engagement. ${ }^{8}$ Furthermore, religiosity's differential effects as a function of political engagement were not attributable to ethno-religious group differences.

\section{Does Political Engagement Moderate the Religiosity-Politics Associations Across all of the Major Ethno-Religious Groups?}

As displayed in the initial set of analyses, ethno-religious group memberships in many cases predicted political characteristics and moderated the relations between religiosity and these political characteristics. Given these initial findings and the historical political importance of ethno-religious groups, we examined whether political engagement moderated the relation between religiosity and conservatism among each of the major ethno-religious groups.

Tables 4 through 8 display the moderation findings among each of the four major ethnoreligious groups (Tables 4 through 7) and among individuals with no religious affiliation (Table 8). Political engagement significantly moderated the relation between religiosity and the political orientation composite among White Evangelical Protestants $(b=.18, p<.001)$, Black Protestants $(b=.12, p<.05),{ }^{9}$ White Catholics $(b=.09, p<.05)$, and the religiously unaffiliated $(b=.24$, $p<.05)$. The political engagement $\times$ religiosity interaction was in the same direction, but was not statistically significant, among White Mainline Protestants $(b=.04, p=.446)$.

Across the ethno-religious groups, there was variability in the particular political characteristics whose relations with religiosity were moderated by political engagement. Among White Evangelical Protestants, the interaction effect was in the predicted direction for all unique political characteristics besides immigration policy preference, but it was only statistically significant for three of these political characteristics (see Table 4). Among White Mainline Protestants, the interaction effect was in the predicted direction for 8 of the 12 unique political characteristics, but the size of these effects were small and none approached statistical significance (see Table 5). In fact, moderation effects in the opposite direction were observed for inequality value $(b=-.15, p=.050)$ and ideological identification $(b=-.20, p=.058)$. Among Black Protestants, the interaction effect was in the predicted direction for all of the unique political characteristics except social welfare, environmental, and immigration preferences, but it was only statistically significant for four of these characteristics (see Table 6). Among White Catholics, the interaction effect was in the predicted direction for all unique political characteristics besides gun control preference, but this effect only approached or reached statistical significance for four of these characteristics (see Table 7). Finally, among the

\footnotetext{
${ }^{8}$ We conceptualize political engagement as a multifaceted construct involving both subjective interest in and objective knowledge about politics. However, interest in politics is conceptually distinguishable from knowledge about politics. We therefore conducted additional analyses that separately examined political interest and political knowledge as moderators of the religiosity-politics relations.

Political interest and political knowledge were moderately correlated $(r=.39, p<.001)$. More importantly, these variables displayed similar patterns as moderators of the associations between religiosity and political characteristics. For all but two of the unique political characteristics assessed, either both interest and knowledge at least near-significantly (at $p<.10)$ moderated the religiosity-politics relation (in the same direction) or neither variable near-significantly or significantly moderated this relation. The exceptions were cultural policy preferences, whose relation with religiosity was moderated by political knowledge $(b=.09, p<.001)$ but not political interest $(b=.03, p=.504)$, and ideological identification, whose relation with religiosity was moderated by political knowledge $(b=.06, p=.087)$ but not political interest $(b=.02$, $p=.658)$. Both political interest $(b=.11, p<.001)$ and political knowledge $(b=.11, p<.001)$ significantly moderated the relation between religiosity and the political orientation composite. All of these moderation effects were in the same direction: high interest and high knowledge were both associated with more of a relation between religiosity and conservative position. Notwithstanding the minor differences, these results indicate that compositizing across political interest and knowledge does not obscure marked differences in the status of these variables as moderators of the religiosity-politics relation.

${ }^{9}$ Black Protestants and Black non-Protestants did not significantly differ in the magnitude of the political engagement $\times$ religiosity interaction effect $(p=.650)$.
} 


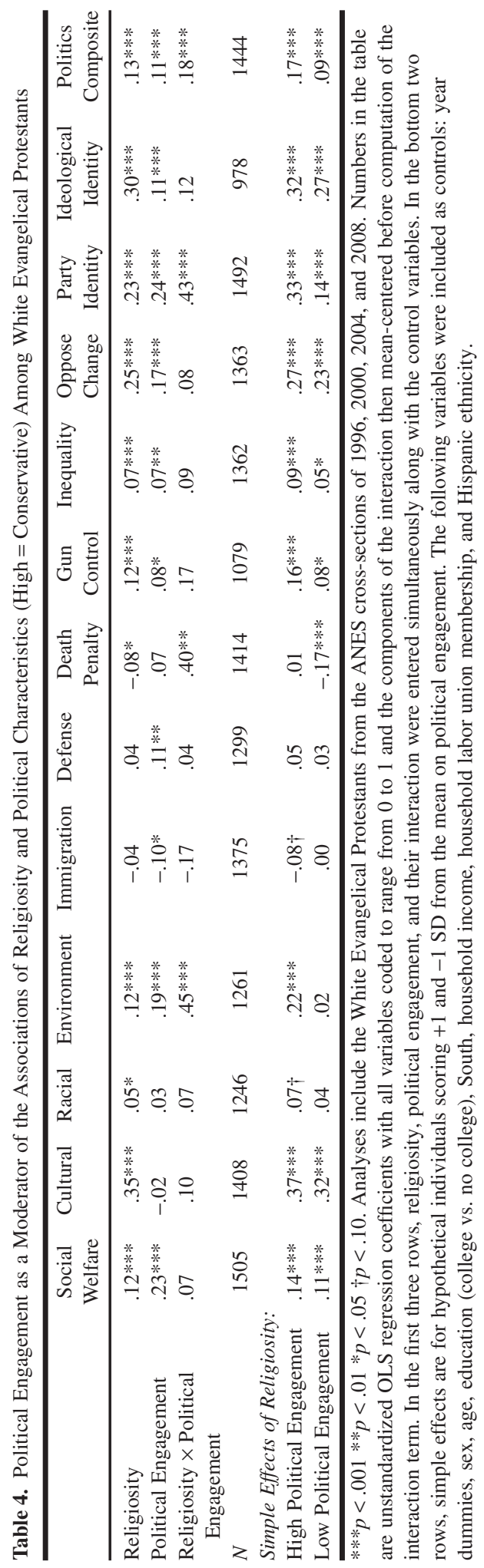




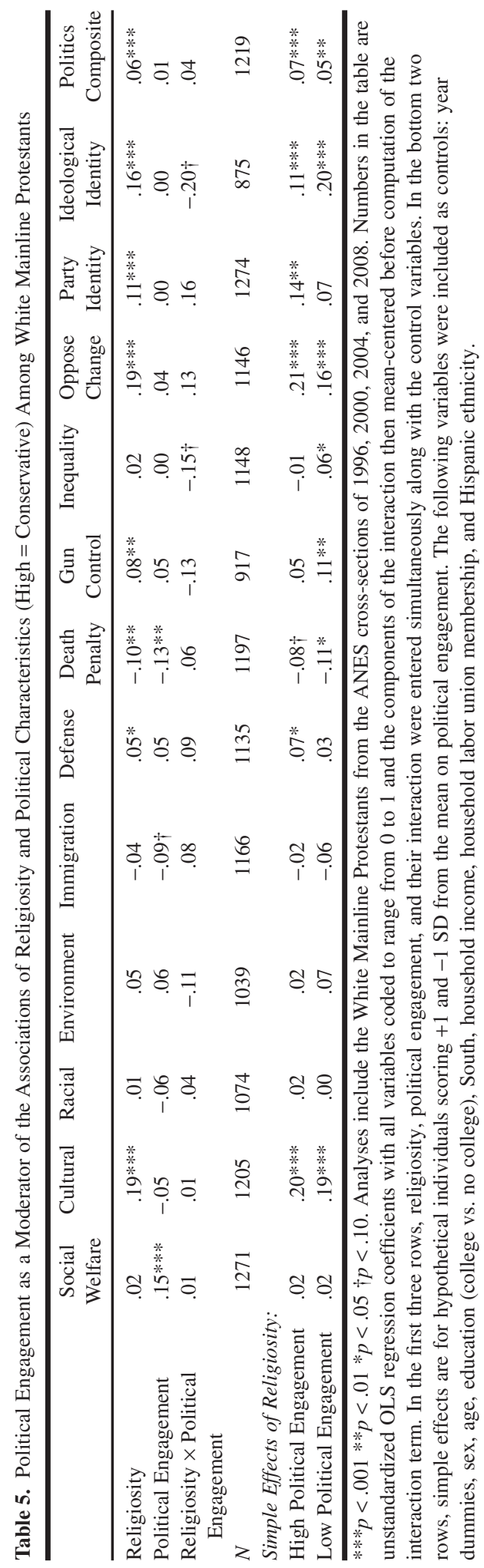




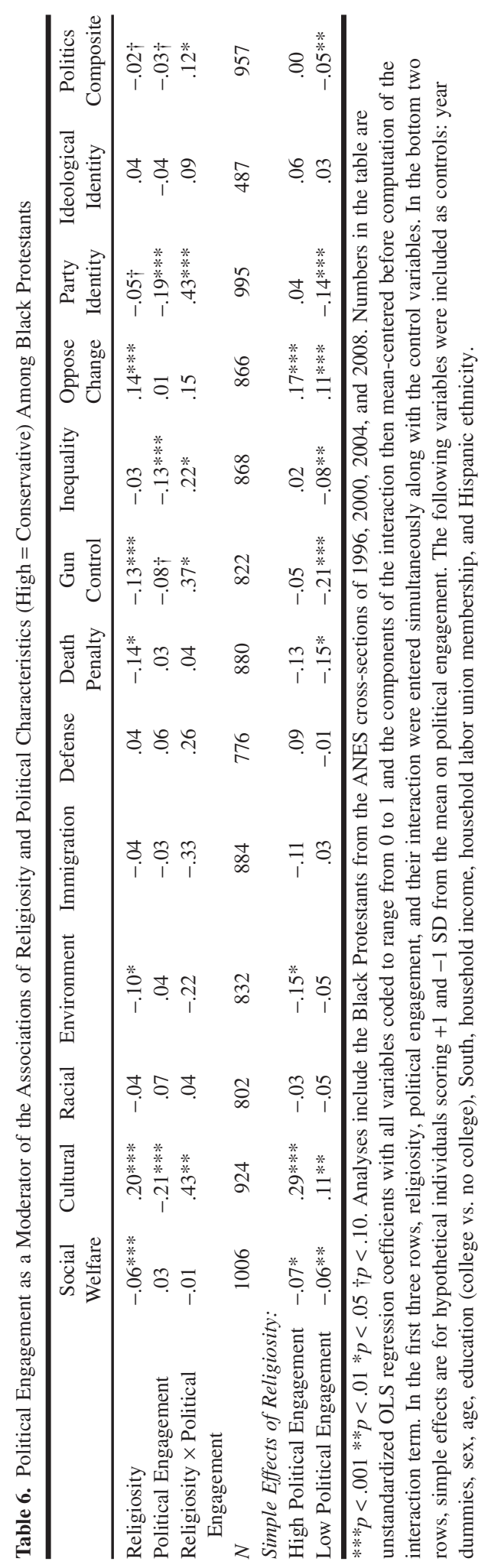




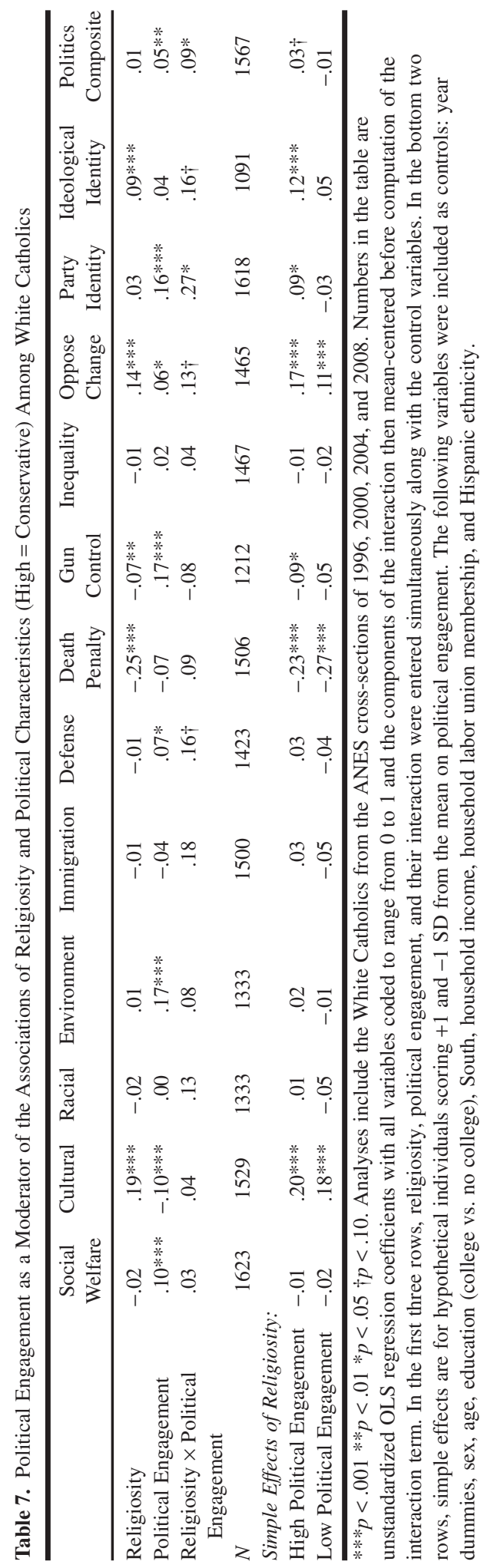




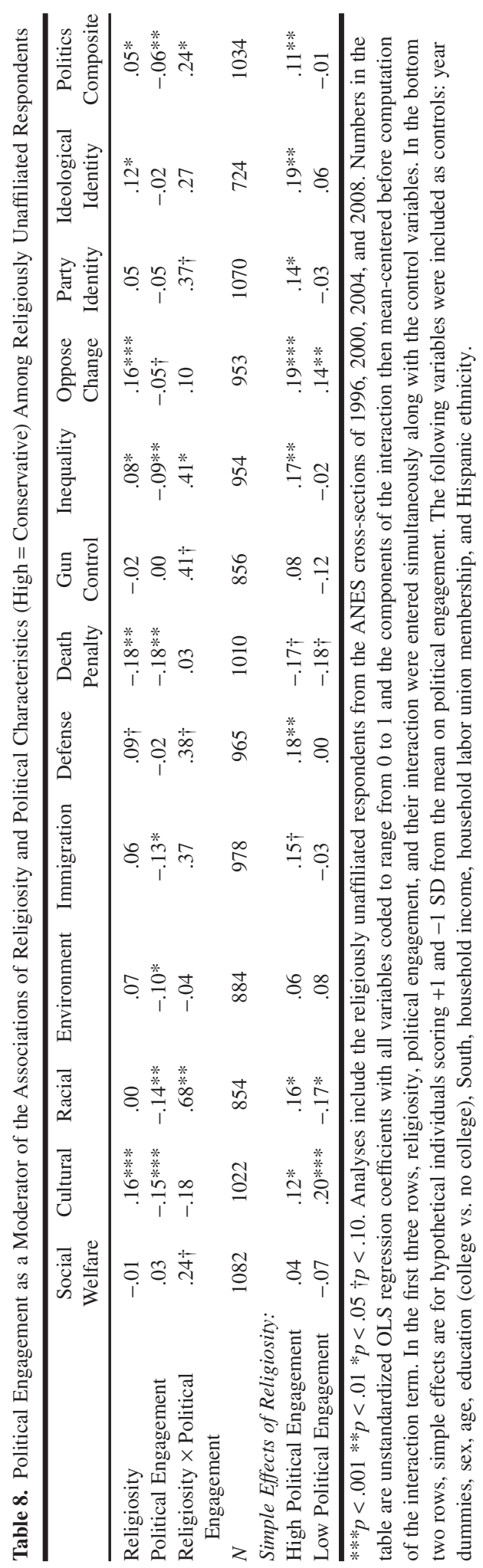


religiously unaffiliated, the interaction effect was in the predicted direction for all unique political characteristics besides cultural and environmental preferences, but this effect only approached or reached statistical significance for six of these characteristics (see Table 8).

In sum, the relation between religiosity and a general conservative orientation toward politics, as represented by the political orientation composite, was moderated by political engagement for all of the major ethno-religious groups besides White Mainline Protestants. The moderated effects of religiosity on the individual political characteristics among the other major ethno-religious groups (and among the religiously unaffiliated) were generally in the predicted direction but usually not statistically significant.

\section{Discussion}

Though the culture wars framework may exaggerate political divisions among ordinary Americans and the degree to which they map onto sociological characteristics (e.g., Fiorina et al., 2006), there is indeed a religious gap in political attitudes and behavior among contemporary Americans (Guth et al., 2006; Layman, 2001; Layman \& Carmines, 1997; Layman \& Green, 2005; Olson \& Green, 2006). Those with greater levels of religious commitment are more inclined to hold conservative political positions than are those with lower levels of religious commitment. We tested whether the widely demonstrated relation between religiosity and conservatism is contingent on engagement with political discourse. We examined as outcome variables a wide range of policy preferences, the core values posited to underlie these policy preferences, and the political identities that correlate with these policy preferences.

Across the entire sample, the relation between religiosity and political orientation varied significantly as a function of political engagement. Among those high in political engagement, the more religious were generally more inclined than were the less religious to adopt the issue stances and values nowadays described as conservative, and they were also more likely than the less religious to identify as Republican. Among those low in political engagement, in contrast, there was no relation between religiosity and most of the political characteristics sampled. Among those low in political engagement, the more religious did tend toward conservative cultural stances, opposition to change, Republican self-identification, and conservative self-identification, which resulted in a small tendency toward overall conservative political orientation. Regarding these political characteristics, it is possible that the cues of religious elites are sufficient to inform religious individuals about the appropriate positions on these dimensions without additional exposure to political discourse (Layman \& Green, 2005). However, engagement with political discourse still does seem to enhance religiosity's relations with cultural policy preferences, opposition to change, and Republican self-identification. Finally, religiosity was associated with opposition to the death penalty, and this relation appeared to be largely counteracted by engagement with political discourse.

It is commonly stated or implied that religiosity and conservative political attitudes are inherently related. For example, in a study demonstrating diverse correlates of ideological self-label, including aspects of religiosity, Jost et al. (2008) argued that the psychological roots of political ideology help explain an apparent historical consistency in the structure and correlates of right versus left ideology. The fact that religiosity and conservative political attitudes are generally correlated is suggested to reflect a deep-seated psychological linkage (Jost, 2007; Jost et al., 2008). Similarly, Alford et al. (2005) argued that the heritability of political attitudes and related characteristics such as religiosity helps explain "the otherwise puzzling consistency in ideological divisions that is present across space and time" (p. 164). Other scholars have suggested that both religious sentiment and support for existing systems of authority serve similar underlying needs (Kay, Gaucher, Napier, Callan, \& Laurin, 2008). 
That religiosity was related to cultural policy preferences, opposition to change, Republican identity, and conservative identity among those low in political engagement is consistent with the possibility that certain components of what is nowadays described as conservative ideology may possess some type of organic linkage with religiosity. For example, it is possible that certain underlying dispositions in part drive both religiosity and a tendency to favor cultural traditionalism, oppose change, and view oneself as Republican and conservative (Jost et al., 2003). Indeed, behavioral genetics studies tend to find notable heritable components to both religiosity and a range of political attitudes (Alford et al., 2005; Eaves, Eysenck, \& Martin, 1989), suggesting that basic predispositions to some extent drive both. However, when considering the full range of preferences and values associated with "conservatism" nowadays, engagement with political communication seems to be the predominant factor that drives the alignment of religiosity and political orientation.

Ethno-religious group memberships have historically mapped onto political cleavages in the United States (Hunter, 1991; Wald, 2003), and they continue to do so (Guth et al., 2006; Layman, 2001; Layman \& Green, 2005). As in other recent studies, we found that members of the predominantly White ethno-religious groups-Evangelical Protestants, Mainline Protestants, and Catholics-were more likely to adopt conservative political stances than were individuals with no religious affiliation. Moreover, White Evangelical Protestants were more conservative than White Mainline Protestants, and White Mainline Protestants were slightly more conservative than White Catholics. Black Protestants adopted left-leaning stances relative to the other major ethno-religious groups and relative to those with no formal religious affiliation. We also found that the relation between religiosity and political attitudes varied across ethno-religious groups-with White Evangelical Protestants displaying a particularly strong relation between religiosity and conservative political orientation, Black Protestants displaying a negative relation, and White Catholics displaying no relation (Cohen et al., 2009; Gallup, 2009). Nonetheless we found that political engagement moderated the relation of religiosity and general political orientation among three of the four major ethno-religious groups (excluding only White Mainline Protestants) and among the religiously unaffiliated. One possibility suggested by these findings is that politically engaged religious conservatives have switched out of Mainline Protestant denominations (e.g., Pew Forum on Religion and Public Life, 2009). Future research should explore this possibility using assessments of interdenominational conversion.

It appears, nonetheless, that the phenomenon presently under study is not driven by differences among ethno-religious groups in the political characteristics examined here. The general moderation finding occurred when controlling for ethno-religious group memberships; thus it is not the result of certain ethno-religious groups possessing particular combinations of religiosity and political engagement. As for the mechanisms involved in the present phenomenon, we think that it is likely that politically engaged individuals tend to adjust their political attitudes to correspond "appropriately" with their levels of religiosity. Indeed, prior research suggests that Americans sometimes adjust their political positions to correspond with politically relevant identities (Cohen, 2003; Carmines \& Stimson, 1989; Gerber \& Jackson, 1993; Goren, Federico, \& Kittilson, 2009; Layman \& Carsey, 2002; Malka \& Lelkes, 2010; Rahn, 1993). However, it is also possible that politically engaged individuals adjust their religiosity levels to correspond with their political orientations. For example, an individual who holds liberal political attitudes and who is exposed to discourse indicating that liberalism goes with secularism may decide that she is not religious as a result. Both of these causal directions are consistent with the more general thesis that political engagement leads people to align their religiosity levels and political orientations.

It is also possible that possessing aligned (vs. misaligned) levels of religiosity and political orientation causes people to become more (vs. less) engaged with politics. For example, a religious conservative may decide based on the discourse to which she is exposed that politics is interesting for her, whereas a religious liberal may decide that it is not. However, our initial findings regarding 
temporal change in the religiosity-politics link in the early 1990s suggest that changes in context of information can influence the degree to which religiosity and politics are aligned (see Figure 1). Thus, even if aligned individuals tend to become more engaged with politics, it is reasonable to expect that differences among people in engagement with political information also influences the degree to which religiosity and politics are aligned. We look forward to research testing causal direction using longitudinal and experimental methodology.

It is noteworthy that the relations of religiosity and individual political characteristics were inconsistently moderated by political engagement among members of the individual ethno-religious groups. Although the association of religiosity with general political orientation was moderated by political engagement among White Evangelical Protestants, Black Protestants, White Catholics, and the religiously unaffiliated, the religiosity $\times$ political engagement interaction was often a nonsignificant predictor of individual political characteristics within each of these groups. However, when combined across the entire sample, the religiosity $\times$ political engagement interaction was a significant predictor of most of the individual political characteristics. Moreover, within these particular ethno-religious groups, a strong majority of the moderation findings were in the predicted direction. This pattern suggests that the moderated effects of religiosity on specific political characteristics are generally small (and require a large sample to be detected), but that they add up to a more robust moderated effect of religiosity on overall conservative orientation.

White Mainline Protestants constituted the exception to this pattern. In fact, politically engaged White Mainline Protestants were less likely to translate religiosity into conservative identity and opposition to equality than were their low political engagement counterparts. This may reflect the unique historical emphases of Mainline Protestantism (e.g., Guth et al., 2006), although it is unclear why these historical emphases would not produce this pattern across other political characteristics. Future research is needed to resolve this question.

\section{Conclusion}

Since the time of the French Revolution, political discourse across many societies has conveyed that a right-left political dimension is relevant to a range of substantive political and social attitudes. One characteristic that has been stated at various times to "go with" this ideological dimension is support of, and commitment to, traditional religious institutions. Our evidence suggests that, among contemporary Americans, the link between being a religious person and being a politically conservative person is largely a product of engagement with political discourse. One implication of these findings is that the particular issue stances and values that are nowadays discussed in terms of a right-left political dimension would correlate differently with religiosity within different contexts of information. We hope that the present analyses are supplemented with cross-national, time-series, longitudinal, and experimental analyses to enhance understanding of how context of information influences the relation between these two socially significant constructs.

\section{ACKNOWLEDGMENTS}

Thanks to Stanley Feldman and the three anonymous reviewers for helpful comments on earlier versions of this article. Correspondence should be sent to Ariel Malka, Yeshiva College, Yeshiva University, 2495 Amsterdam Avenue, New York, NY 10033. E-mail: amalka@yu.edu

\section{REFERENCES}

Alford, J. R., Funk, C. L., \& Hibbing, J. R. (2005). Are political orientations genetically transmitted? American Political Science Review, 99, 153-167. 
American National Election Studies. (1996). The 1996 National Election Study [data set]. Ann Arbor, MI: University of Michigan, Center for Political Studies [producer and distributor]. www.electionstudies.org

American National Election Studies. (2000). The 2000 National Election Study [data set]. Ann Arbor, MI: University of Michigan, Center for Political Studies [producer and distributor]. www.electionstudies.org

American National Election Studies. (2004). The 2004 National Election Study [data set]. Ann Arbor, MI: University of Michigan, Center for Political Studies [producer and distributor]. www.electionstudies.org

American National Election Studies. (2008). The ANES 2008 Time Series Study [data set]. Stanford University and the University of Michigan [producers]. www.electionstudies.org

Baldassari, D., \& Gelman, A. (2008). Partisans without constraint: Political polarization and trends in American public opinion. American Journal of Sociology, 114, 408-446.

Bartels, L. M. (1993). The political impact of media exposure. American Political Science Review, 87, $267-285$.

Campbell, A., Converse, P. E., Miller, W. E., \& Stokes, D. E. (1960). The American voter. Chicago: John Wiley \& Sons.

Carmines, E. G., \& Stimson, J. A. (1989). Issue evolution: Race and the transformation of American politics. Princeton, NJ: Princeton University Press.

Cohen, A. B., Malka, A., Hill, E. C., Thoemmes, F., Hill, P. C., \& Sundie, J. M. (2009). Race as a moderator of the relationship between religiosity and political alignment. Personality and Social Psychology Bulletin, 35, 271-282.

Cohen, G. L. (2003). Party over policy: The dominating impact of group influence on political beliefs. Journal of Personality and Social Psychology, 85, 808-822.

Converse, P. E. (1964). Nature of belief systems in mass publics. In D. Apter (Ed.), Ideology and Discontent (pp. 206-261). New York: Free Press.

Davis, N., \& Robinson, R. (1996). Are the rumors of war exaggerated? Religious orthodoxy and moral progressivism in America. American Journal of Sociology, 102, 756-787.

Delli Carpini, M. X., \& Keeter, S. (1996). What Americans know about politics and why it matters. New Haven, CT: Yale University Press.

Eaves, L. J., Eysenck, H. J., \& Martin, N. G. (1989). Genes, culture, and personality: An empirical approach. San Diego: Academic Press.

Federico, C. M., \& Goren, P. (2009). Motivated social cognition and ideology: Is attention to elite discourse a prerequisite for epistemically motivated political affinities? In J. T. Jost, A. C. Kay, \& H. Thorisdottir (Eds.), Social and psychological bases of ideology and system justification (pp. 267-291) New York: Oxford University Press.

Federico, C., Hunt, C. V., \& Ergun, D. (2009). Political expertise, social worldviews, and ideology: Translating "competitive jungles" and "dangerous worlds" into ideological reality. Social Justice Research, 22, 259-279.

Fiorina, M. P., Abrams, S. J., \& Pope, J. C. (2006). Culture war? The myth of a polarized America (2nd ed). New York: Pearson Longman.

Gallup (2004). Americans and the death penalty. http://www.gallup.com/poll/14371/Americans-Death-Penalty.aspx

Gallup (2009). Catholics similar to mainstream on abortion, stem cells: Catholics actually more liberal on some issues. http://www.gallup.com/poll/117154/catholics-similar-mainstream-abortion-stem-cells.aspx

Ganzach, Y. (1997). Misleading interaction and curvilinear terms. Psychological Methods, 2, 235-237.

Gerber, E. R., \& Jackson, J. E. (1993). Endogenous preferences and the study of institutions. American Political Science Review, 87, 639-656.

Gerring, J. (1998). Party ideologies in America, 1828-1996. New York: Cambridge University Press.

Goren, P., Federico, C. M., \& Kittilson, M. C. (2009). Source cues, partisan identities, and political value expression. American Journal of Political Science, 53, 805-820.

Graham, J., Haidt, J., \& Nosek, B. A. (2009). Liberals and conservatives rely on different sets of moral foundations. Journal of Personality and Social Psychology, 96, 1029-1046.

Green, J. C., Guth, J. L., \& Fraser, C. R. (1991). Apostles and apostates? Religion and politics among party activists. In J. L. Guth \& J. C. Green (Eds.), The Bible and the ballot box: Religion and politics in the 1988 election (pp. 113-136). Boulder, CO: Westview.

Guth, J. L., Green, J. C., Smidt, C. E., Kellstedt, L. A., \& Poloma, M. M. (1997). The bully pulpit: The politics of Protestant clergy. Lawrence: University Press of Kansas.

Guth, J. L., Kellstedt, L. A., Smidt, C. E., \& Green, J. C. (2006). Religious influences in the 2004 presidential election. Presidential Studies Quarterly, 36, 223-242.

Hill, P. C., \& Pargament, K. I. (2003). Advances in the conceptualization and measurement of religion and spirituality. Implications for physical and mental health research. American Psychologist, 58, 64-74.

Hillygus, D. S., \& Shields, T. G. (2005). Moral issues and voter decision making in the 2004 presidential election. PS: Political Science \& Politics, 38, 201-209. 
Hunter, J. D. (1991). Culture wars: The struggle to define America. New York: Basic Books.

Iyengar, S., \& Kinder, D. (1987). News that matters. Chicago: University of Chicago Press.

Jacoby, W. G. (1995). The structure of ideological thinking in the American electorate. American Journal of Political Science, 39, 314-335.

Jelen, T. G. (2009). Religion and American public opinion: Social issues. In C. E. Smidt, L. A. Kellstedt, \& J. L. Guth (Eds.), The Oxford handbook of religion and American politics (pp. 217-242). New York: Oxford University Press.

Jost, J. T. (2006). The end of the end of ideology. American Psychologist, 61, 651-670.

Jost, J. T. (2007). Coda: After "The end of the end of ideology"-Reply to Glassman and Karno (2007) and Unger (2007). American Psychologist, 62, 1077-1080.

Jost, J. T., Glaser, J., Kruglanski, A. W., \& Sulloway, F. J. (2003). Political conservatism as motivated social cognition. Psychological Bulletin, 129, 339-375.

Jost, J. T., Nosek, B. A., \& Gosling, S. D. (2008). Ideology: Its resurgence in social, personality, and political psychology. Perspectives on Psychological Science, 3, 126-136.

Judd, C. M., \& Krosnick, J. A. (1989). The structural bases of consistency among political attitudes: The effects of political expertise and attitude importance. In A. R. Pratkanis, S. J. Breckler, \& A. G. Greenwald (Eds.), Attitude structure and function (pp. 99-128). Hillsdale, NJ: Lawrence Erlbaum.

Katz, E., \& Lazarsfeld, P. F. (1955). Personal influence. Glencoe, IL: Free Press.

Kay, A. C., Gaucher, D., Napier, J. L., Callan, M. J., \& Laurin, K. (2008). God and the government: Testing a compensatory control mechanism for the support of external systems. Journal of Personality and Social Psychology, 95, 18-35.

Kellstedt, L. A., \& Green, J. C. (1993). Knowing God's many people: Denominational preference and political behavior. In D. C. Leege \& L. A. Kellstedt (Eds.), Rediscovering the religious factor in American politics (pp. 53-71). Armonk, NY: M. E. Sharpe.

Kelly, N. J., \& Morgan, J. (2008). Religious traditionalism and Latino politics in the United States. American Politics Research, 36, 236-263.

Kohut, A., Green, J. C., Keeter, S., \& Toth, R. C. (2000). Diminishing divide: Religion's changing role in American politics. Washington, DC: Brookings.

Layman, G. C. (2001). The great divide: Religious and cultural conflict in American party politics. New York: Columbia University Press.

Layman, G. C., \& Carmines, E. G. (1997). Cultural conflict in American politics: Religious traditionalism, postmaterialism, and U.S. political behavior. Journal of Politics, 59, 751-777.

Layman, G. C., \& Carsey, T. M. (2002). Party polarization and party structuring of policy attitudes: A comparison of three NES panel studies. Political Behavior, 24, 199-236.

Layman, G. C., \& Green, J. C. (2005). Wars and rumours of wars: The contexts of cultural conflict in American political behavior. British Journal of Political Science, 36, 61-89.

Leege, D. C., \& Kellstedt, L. A. (Eds.), (1993). Rediscovering the religious factor in American politics. Armonk, NY: M. E. Sharpe.

Lincoln, C. E., \& Mamiya, L. H. (1990). The Black church in the African American experience. Durham, NC: Duke University Press.

Malka, A., \& Lelkes, Y. (2010). More than ideology: Conservative-liberal identity and receptivity to political cues. Social Justice Research, 23, 156-188.

Mutz, D. C. (1998). Impersonal influence: How perceptions of mass collectives affect political attitudes. Cambridge: Cambridge University Press.

Mutz, D. C. (2002). The consequences of cross-cutting networks for political participation. American Journal of Political Science, 46, 838-855.

Olson, L. R., \& Green, J. C. (2006). The religion gap. PS: Political Science \& Politics, 39, 455-59.

Pew Forum On Religion and Public Life (2005). Religion and public life: A faith-based partisan divide. http://pewforum.org/ uploadedfiles/Topics/Issues/Politics_and_Elections/religion-and-politics-report.pdf

Pew Forum on Religion and Public Life (2008). U.S. religious landscape survey: Religious affiliation: Diverse and dynamic. http://religions.pewforum.org/pdf/report-religious-landscape-study-full.pdf

Pew Forum on Religion and Public Life (2009). Faith in flux: Changes in religious affiliation in the U.S. http://pewforum.org/ uploadedfiles/Topics/Religious_Affiliation/fullreport.pdf

Rahn, W. M. (1993). The role of partisan stereotypes in information processing about political candidates. American Journal of Political Science, 37, 472-496.

Roof, W. C., \& McKinney, W. (1987). American mainline religion: Its changing shape and future. Piscataway, NJ: Rutgers University Press. 
Smidt, E. C., Kellstedt, L. A., \& Guth, J. L. (2009). The role of religion in American politics: Explanatory theories and associated analytical and measurement issues. In C. E. Smidt, L. A. Kellstedt, \& J. L. Guth (Eds.), The Oxford handbook of religion and American politics (pp. 3-42). New York: Oxford University Press.

Sniderman, P. M., Brody, R. A., \& Tetlock, P. E. (1991). Reasoning and choice: Explorations in political psychology. New York: Cambridge University Press.

Sniderman, P. M., \& Bullock, J. (2004). A consistency theory of public opinion and political choice: The hypothesis of menu dependence. In W. E. Saris \& P. M. Sniderman (Eds.), Studies in public opinion: Attitudes, nonattitudes, measurement error, and change (pp. 337-358). Princeton, NJ: Princeton University Press.

Stark, R., \& Finke, R. (2000). Acts of faith: Explaining the human side of religion. Berkeley: University of California Press.

Steensland, B., Park, J. Z., Regnerus, M. D., Robinson, L. D., Wilcox, W. B., \& Woodberry, R. D. (2000). The measure of American religion: Toward improving the state of the art. Social Forces, 79, 291-318.

Stimson, J. A. (1975). Belief systems: Constraint, complexity, and the 1972 election. American Journal of Political Science, 19, 393-417.

Thorisdottir, H., Jost, J. T., Levitan, I., \& Shrout, P. E. (2007). Psychological needs and values underlying left-right political orientation: Cross-national evidence from Eastern and Western Europe. Public Opinion Quarterly, 71, $175-203$.

Wald, K. (2003). Religion and politics in the United States. Lanham, MD: Rowman and Littlefield.

Wilcox, C., \& Larsen, C. (2006). Onward Christian soldiers? The religious right in American politics (3rd ed.). Boulder, CO: Westview.

Williams, R. H. (1997). Cultural wars in American politics: Critical reviews of a popular myth. New York: Aldine de Gruyter.

Wuthnow, R. (1988). The restructuring of American religion: Society and faith since World War II. Princeton, NJ; Princeton University Press.

Zaller, J. R. (1992). The nature and origins of mass opinion. New York: Cambridge University Press.

Appendix: Indicators Used Across ANES 1996, 2000, 2004, and 2008 Cross-Sections

\begin{tabular}{|c|c|c|c|c|c|c|}
\hline \multirow[t]{2}{*}{ Measure } & \multirow[t]{2}{*}{ Items Comprising Composite } & \multirow{2}{*}{$\begin{array}{c}\text { Cronbach's } \\
\text { Alpha }\end{array}$} & \multicolumn{4}{|c|}{ Years Available } \\
\hline & & & 1996 & 2000 & 2004 & 2008 \\
\hline Ethno-religious & Religious denomination, racial-ethnic group & - & Yes & Yes & Yes & Yes \\
\hline Group & $\begin{array}{l}\text { Evangelical/fundamentalist identification, born-again } \\
\text { experience, and liturgical literalism }\end{array}$ & & & & & \\
\hline \multirow[t]{2}{*}{ Religiosity } & Frequency of religious attendance & .73 & Yes & Yes & Yes & Yes \\
\hline & Amount of guidance religion provides in your life & & Yes & Yes & Yes & Yes \\
\hline \multirow[t]{6}{*}{ Political Interest } & Interest in presidential campaigns & .67 & Yes & Yes & Yes & Yes \\
\hline & Care about presidential election outcome & & Yes & Yes & Yes & Yes \\
\hline & Interest in government and public affairs & & Yes & Yes & Yes & Yes $^{\mathrm{a}}$ \\
\hline & $\begin{array}{l}\text { Frequency of political discussion with family and } \\
\text { friends }\end{array}$ & & Yes & Yes & Yes & Yes $^{\mathrm{a}}$ \\
\hline & Frequency of reading newspaper & & Yes & Yes & Yes & Yes $^{\mathrm{a}}$ \\
\hline & Frequency of watching television news & & Yes & Yes & Yes & Yes $^{\mathrm{a}}$ \\
\hline \multirow[t]{5}{*}{ Political Knowledge } & Which party more conservative? & .67 & Yes & Yes & Yes & Yes \\
\hline & Which party controls the House of Representatives? & & Yes & Yes & Yes & Yes \\
\hline & Which party controls the Senate? & & Yes & Yes & Yes & Yes \\
\hline & Identify Congressional Leader & & Yes & Yes & Yes & No \\
\hline & Identify Chief Justice of Supreme Court & & Yes & Yes & Yes & No \\
\hline \multirow[t]{9}{*}{ Social Welfare } & Private vs. government health insurance & .82 & Yes & Yes $^{\mathrm{b}}$ & Yes & Yes $^{\mathrm{a}}$ \\
\hline & Government guaranteed jobs and standard of living & & Yes & Yes $^{\mathrm{b}}$ & Yes & Yes $^{\mathrm{c}}$ \\
\hline & Government spending and services & & Yes & Yes $^{\mathrm{b}}$ & Yes & Yes $^{\mathrm{a}}$ \\
\hline & Aid to the poor ${ }^{d}$ & & Yes & Yes & Yes & Yes \\
\hline & Child care spending & & Yes & Yes & Yes & Yes \\
\hline & Public schools spending & & Yes & Yes & Yes & Yes \\
\hline & Homelessness spending & & Yes & Yes & Yes & No \\
\hline & Welfare programs spending & & Yes & Yes & Yes & Yes \\
\hline & Social security spending & & Yes & Yes & Yes & Yes \\
\hline
\end{tabular}




\section{Appendix (cont.)}

\begin{tabular}{|c|c|c|c|c|c|c|}
\hline \multirow[t]{2}{*}{ Measure } & \multirow[t]{2}{*}{ Items Comprising Composite } & \multirow{2}{*}{$\begin{array}{c}\text { Cronbach's } \\
\text { Alpha }\end{array}$} & \multicolumn{4}{|c|}{ Years Available } \\
\hline & & & 1996 & 2000 & 2004 & 2008 \\
\hline \multirow[t]{5}{*}{ Cultural } & Women's place in home vs. equal role & .69 & Yes & Yes $^{\mathrm{b}}$ & Yes & $\mathrm{Yes}^{\mathrm{c}}$ \\
\hline & Abortion legality & & Yes & Yes & Yes & Yes $^{c}$ \\
\hline & Protect homosexuals against job discrimination & & Yes & Yes & Yes & Yes \\
\hline & Homosexuals in the military & & Yes & Yes & Yes & Yes \\
\hline & Allow homosexuals to adopt children & & No & Yes & Yes & Yes \\
\hline \multirow[t]{3}{*}{ Racial } & Aid to blacks & .69 & Yes & Yes $^{\mathrm{b}}$ & Yes & Yes \\
\hline & Affirmative action for Black Americans ${ }^{d}$ & & Yes & Yes & Yes & Yes \\
\hline & Ensure fair treatment in jobs for Black Americans ${ }^{\mathrm{e}}$ & & Yes & Yes & Yes & Yes \\
\hline Environmental & Environmental spending & - & Yes & Yes & No & Yes \\
\hline Immigration & Permit fewer vs. more immigrants & - & Yes & Yes & Yes & Yes \\
\hline Defense & Defense spending & - & Yes & Yes $^{\mathrm{b}}$ & Yes & Yes $^{\mathrm{a}}$ \\
\hline Death Penalty & Death penalty for murder & - & Yes & Yes & Yes & Yes \\
\hline Gun Control & Should be easier vs. more difficult to buy gun & - & No & Yes & Yes & Yes \\
\hline \multirow[t]{6}{*}{ Inequality Value } & Ensure equal opportunity to succeed & .69 & Yes & Yes & Yes & Yes \\
\hline & Have gone too far in pushing equal rights & & Yes & Yes & Yes & Yes \\
\hline & Big problem that not everyone has equal chance & & Yes & Yes & Yes & Yes \\
\hline & Not a big problem if some have greater chance & & Yes & Yes & Yes & Yes \\
\hline & Should worry less about inequality & & Yes & Yes & Yes & Yes \\
\hline & Would be fewer problems if more equality & & Yes & Yes & Yes & Yes \\
\hline \multirow[t]{4}{*}{ Oppose Change Value } & Newer lifestyles contribute to societal breakdown & .63 & Yes & Yes & Yes & Yes \\
\hline & Should adjust view of morality to changing world & & Yes & Yes & Yes & Yes \\
\hline & More emphasis on traditional values & & Yes & Yes & Yes & Yes \\
\hline & Tolerance of different moral standards & & Yes & Yes & Yes & Yes \\
\hline Party Identification & $\begin{array}{l}\text { Republican vs. Democratic self-placement } \\
\text { (7-point scale) }\end{array}$ & - & Yes & Yes & Yes & Yes \\
\hline $\begin{array}{l}\text { Ideological } \\
\text { Identification }\end{array}$ & $\begin{array}{l}\text { Conservative vs. liberal self-placement } \\
\text { (7-point scale) }\end{array}$ & - & Yes & Yes & Yes & Yes \\
\hline
\end{tabular}

${ }^{a}$ Respondents were randomly assigned to differently worded versions of this item.

${ }^{b}$ Number of response options (7 vs. 5) varied across respondents depending on mode of interview.

'Only a random half of respondents received this item; the other half was counted as not having provided a usable response.

${ }^{\mathrm{d}}$ Respondents in different years responded to differently worded versions of this item.

${ }^{\mathrm{e}}$ Only respondents who indicated that they had an interest in this issue were asked this question. 